\title{
Pengaruh Biodelignifikasi Daun Sawit Menggunakan Kapang Phanerochaete Chrysosporium Yang Disuplementasi Dengan Mineral Ca Terhadap Karakteristik Cairan Rumen Secara In Vitro
}

\author{
Sri Rahayu \\ Program Studi Peternakan Fakultas Pertanian \\ Universitas Jabal Ghafur
}

\begin{abstract}
The aims of this research to see the effect of biodelignification of palm leaves using Phanerochaete chrysosporium againts total VFA, $\mathrm{NH} 3$ and $\mathrm{pH}$. This study used factorial randomized block design $(4 \times 3)$ with 3 replications. Factor $\mathrm{A}$ is a dose of mineral addition in which $\mathrm{A} 0=0 \mathrm{ppm}$ Ca mineral, $\mathrm{A} 1=1000$ ppm Ca mineral, A3 $=1500 \mathrm{ppm} \mathrm{Ca}$ mineral, and A4 $=2000 \mathrm{ppm} \mathrm{Ca}$ mineral. Factor $\mathrm{Y}$ is the time of fermentation $\mathrm{Y} 1=10$ days, $\mathrm{Y} 2=15$ days, and $\mathrm{Y} 3=20$ days. Fermentation of palm leaves using Phanerochaete chrysosporium at a dose of Ca $2000 \mathrm{ppm}$ mineral with a fermentation time of 10 days showed a total of $121.25 \mathrm{mM}$ VFA more than any other treatment, and the amount of $\mathrm{NH} 3$ produced $14.80 \mathrm{mg} / 100 \mathrm{ml}$ of rumen fluid, and $\mathrm{pH}$ ranges from 6.79 to 6.86 . The resulting $\mathrm{pH}$ is still in a condition where rumen microbes can grow optimally.
\end{abstract}

Key words: Biodelignification, Phanerochaete chrysosporium, NH3, pH, Volatille Fatty Acid (VFA)

\section{Pendahuluan}

Peralihan fungsi lahan menyebabkan semakin sempitnya areal untuk tumbuhnya Hijauan Makanan Ternak (HMT). Oleh karena itu perlu dilakukan upaya untuk memenuhi kebutuhan pakan ternak alternatif, mudah didapat, harga murah, tersedia sepanjang waktu dengan memanfaatkan limbah perkebunan. Salah satu dari limbah perkebuanan tersebut yang dapat dimanfaatkan adalah limbah dari perkebunan kelapa sawit yaitu daun sawit yang berasal dari pemangkasan pelepah daun kelapa sawit. Limbah yang dihasilkan dari perkebunan sawit produksinya melimpah, tidak bersaing dengan kebutuhan manusia, serta pemanfaatan yang belum optimal.

Pemanfaatan daun sawit masih sangat terbatas jika diberikan kepada ternak, hal ini disebabkan karena pelepah sawit mengandung lignin yang tinggi sehingga menyebabkan kecernaan pelepah sawit menjadi rendah. Kandungan protein kasar daun sawit 5.75\% lebih rendah dibandingkan dengan protein kasar rumput 10.07 - $13.87 \%$ (Alimon dan Hair-Bejo, 1996 ; Sirait, dkk. 2005 dalam Simanihuruk, dkk. 2007 ).

Untuk meningkatkan penggunaan daun sawit di dalam ransum diperlukan usaha untuk menurunkan kandungan lignin daun sawit. Salah satu usaha tersebut adalah melakukan fermentasi dengan menggunakan mikroorganisme yang memiliki kemampuan untuk mendegradasi lignin. Phanerochaete chrysosporium adalah kapang dari kelas Basidiomycetes yang mempunyai kemampuan kuat dalam merombak lignin secara efektif (Leisola dan Garcia, 1989 dalam Wulandari, dkk. 2003). Sehingga penggunaan Phanerochaete chrysosporium pada biodelignifikasi daun awit diharapkan dapat memutus ikatan selulosa dan hemiselulosa dari lignin sehingga dapat meningkatkan kualitas daun sawit.

Pertumbuhan kapang Phanerochaete chrysosporium dipengaruhi oleh ketersediaan mineral dalam substrat. Hasil penelitian Nelson (2011) menyebutkan bahwa kapang mencapai pertumbuhan maksimal pada perlakuan penambahan Ca 1190 ppm. Fermentasi dengan menggunakan kapang Phanerochaete chrysosporium merupakan langkah strategis dalam memperbaiki kualitas daun sawit dan untuk meningkatkan kecernaan. Selain dari penambahan mineral $\mathrm{Ca}$ pada penelitian ini juga dilihat pengaruh waktu inkubasi dalam proses delignifikasi. Nelson dan Suparjo (2011) menyatakan bahwa fermentasi kulit buah kakao dengan penambahan $1190 \mathrm{ppm}$ Ca selama 10 hari memberikan hasil yang terbaik yaitu degradasi lignin $(38,61 \%)$, efisiensi biodegradasi lignin $(5,65 \%)$.

\section{MATERI DAN METODE}

Waktu dan Tempat Penelitian Penelitian ini dilaksanakan di Laboratorium Nutrisi Ruminansia Fakultas Peternakan Universitas Andalas. 
Bahan utama yang digunakan dalam penelitian ini adalah daun, kapang Phanerochaete chrysosporium burdsaal IFO, mineral $\mathrm{Ca}, \mathrm{Mc}$ Dougall, medium Potato Dextrose Agar (PDA) dan cairan rumen.

Peralatan yang digunakan dalam penelitian ini adalah seperangkat alat-alat untuk in vitro, Proksimat, Van Soest.

Penelitian ini menggunakan RAK pola Faktorial $(4 \times 3)$ dengan 3 kali ulangan.

$Y i j k=\mu+\alpha i+\beta j+(\alpha \beta) i j+\Sigma i j k$

Faktor $\mathrm{A}$ adalah dosis pemberian mineral, yaitu:

$\mathrm{A} 0=$ Daun sawit $+\mathrm{P}$. chrysosporium tanpa penambahan mineral

$\mathrm{A} 1=$ Daun sawit $+\mathrm{P}$. chrysosporium + mineral Ca 1000 ppm.

$\mathrm{A} 2$ = Daun sawit $+\mathrm{P}$. chrysosporium + mineral Ca 1.500 ppm.

A3 = Daun sawit + P. chrysosporium + mineral Ca 2.000 ppm.

Sedangkan yang menjadi faktor B adalah lama waktu fermentasi yaitu: $\mathrm{Y} 1=10$ hari, $\mathrm{Y} 2=$ 15 hari dan $\mathrm{Y} 3=20$ hari.

Data yang diperoleh dianalisa secara statistik menggunakan analisa varian (Anova) dan untuk melihat perbedaan antar perlakuan dilakukan pengujian dengan menggunakan uji lanjut Duncan's Multiple Range Test (DMRT) (Steel and Torrie, 1991).

\section{HASIL DAN PEMBAHASAN Konsentrasi Amonia (NH3)}

Rataan total NH3 daun sawit yang difermentasi menggunakan kapang Phanerochaete chrysosporium dapat dilihat pada Tabel 1.

Tabel 1. Rataan Total NH3 (mg/ml cairan rumen)

\begin{tabular}{llllll}
\hline $\begin{array}{l}\text { Waktu } \\
(\mathbf{Y})\end{array}$ & $\mathbf{A 0}$ & $\mathbf{A 1}$ & $\mathbf{A 2}$ & $\mathbf{A 3}$ & \\
\hline Y1 & 8.65 & 10.58 & 12.60 & 14.80 & $11.66^{\mathrm{a}}$ \\
Y2 & 8.31 & 9.93 & 11.83 & 14.14 & $11.05^{\mathrm{b}}$ \\
Y3 & 7.51 & 9.39 & 11.03 & 13.45 & $10.35^{\mathrm{c}}$ \\
\hline Rataan & $8.16^{\mathrm{d}}$ & $9.97^{\mathrm{c}}$ & $11.82^{\mathrm{b}}$ & $14.13^{\mathrm{a}}$ & 11.02
\end{tabular}

Ket: Superskrip yang berbeda pada baris dan kolom yang sama menunjukkan berbeda sangat nyata $(\mathrm{P}<0.01)$

Hasil sidik ragam menunjukkan total $\mathrm{NH} 3$ tidak terdapat interaksi $(\mathrm{P}>0.05)$ antara pemberian dosis mineral (A) dengan lama fermentasi (Y), akan tetapi masing-masing faktor yaitu pemberian dosis mineral (A) dan lama fermentasi (Y) memberikan pengaruh sangat nyata $(\mathrm{P}<0.01)$ terhadap peningkatan jumlah NH3 daun sawit yang difermentasi menggunakan kapang Phanerochaete chrysosporium dibandingkan dengan perlakuan lainnya.

Hasil uji lanjut DMRT terhadap pemberian dosis mineral (A) menunjukkan bahwa pada perlakuan A3 berbeda sangat nyata $(\mathrm{P}<0.01)$ terhadap peningkatan jumlah $\mathrm{NH} 3$ dibandingkan dengan perlakuan A0, A1 dan A2. Perlakuan A2 berbeda sangat nyata $(\mathrm{P}<0.01)$ terhadap A1 dan A1 berbeda sangat nyata $(\mathrm{P}<0.01)$ terhadap A0. Hasil uji lanjut DMRT terhadap faktor lama fermentasi (Y) menunjukkan bahwa rataan jumlah $\mathrm{NH} 3$ pada perlakuan Y1 (10 hari) berbeda sangat nyata $(\mathrm{P}<0.01)$ terhadap perlakuan $\mathrm{Y} 2$ dan $\mathrm{Y} 3$, perlakuan $\mathrm{Y} 2$ berbeda sangat nyata $(\mathrm{P}<0.01)$ terhadap perlakuan Y3.

Tingginya jumlah NH3 pada perlakuan penambahan dosis A3 (2000 ppm) dan Y1 (10 hari) hal ini sejalan dengan peningkatan kecernaan protein substrat sebesar $47.54 \%$ (Rahayu, 2014) . Hal ini juga dibuktikan bahwa kandungan PK substrat setelah fermentasi meningkat $17.83 \%$ (Rahayu, 2014). Jumlah protein yang terdegradasi di dalam rumen akan digunakan untuk membentuk NH3 dan $\mathrm{N}$ yang dihasilkan akan digunakan oleh mikroba rumen untuk menunjang pertumbuhannya.

Rendahnya jumlah NH3 pada perlakuan A0 (0 ppm), A1 (1000 ppm), A2 (1500 ppm), Y2 (15 hari) dan Y3 (20 hari) disebabkan karena belum optimalnya kemampuan kapang dalam mensekresikan enzim ligninase sehingga proses degradasi lignin belum terjadi dengan optimal. Hal ini membuat ikatan lignoselulosa dan lignohemiselulosa masih tinggi dan menyebabkan kecernaan nutrient juga rendah.

Semakin banyak protein yang terdegradasi akan semakin banyak NH3 yang terbentuk dan semakin banyak pula mikroba yang tumbuh. Sayuti (1989) menyatakan bahwa peningkatan protein yang terdegradasi akan meningkatkan produksi NH3 dalam rumen. Rataan NH3 yang diperoleh pada penelitian ini berkisar antara $7.51 \mathrm{mg} / 100 \mathrm{ml}-14.80 \mathrm{mg} / \mathrm{ml}$ cairan rumen, nilai tersebut sudah memenuhi kebutuhan untuk mencapai pertumbuhan yang optimal bagi mikroba rumen. Sutardi (1981) menyatakan bahwa konsentrasi ammonia untuk mendukung pertumbuhan mikroba yaitu sebesar $5-17.65 \mathrm{mM}$. 
Konsentrasi Volatile Fatty Acid (VFA)

Rataan total VFA daun sawit yang difermentasi menggunakan kapang Phanerochaete chrysosporium dapat dilihat pada Tabel 2.

Tabel 2. Rataan Total VFA (mM)

\begin{tabular}{llllll}
\hline $\begin{array}{l}\text { Waktu } \\
(\text { Y) }\end{array}$ & A0 & A1 & A2 & A3 & \\
\hline Y1 & $102.18^{1}$ & $106.08^{\mathrm{g}}$ & $116.00^{\mathrm{d}}$ & $121.25^{\mathrm{a}}$ & 111.38 \\
Y2 & $98.88^{\mathrm{j}}$ & $102.04^{\mathrm{h}}$ & $113.06^{\mathrm{e}}$ & $118.16^{\mathrm{b}}$ & 108.04 \\
Y3 & $97.53^{\mathrm{k}}$ & $99.94^{\mathrm{h}}$ & $109.81^{\mathrm{f}}$ & $114.45^{\mathrm{c}}$ & 105.43 \\
\hline Rataan & 99.53 & 102.69 & 112.95 & 117.95 & 108.28
\end{tabular}

Ket: Superskrip yang berbeda pada baris dan kolom yang sama menunjukkan berbeda sangat nyata $(\mathrm{P}<0.01)$

Hasil sidik ragam pada total VFA menunjukkan pengaruh cenderung berinteraksi $(\mathrm{P}<0.10)$ antara pemberian dosis mineral (A) dengan lama fermentasi (Y).

Hasil uji lanjut DMRT terhadap total VFA pada masing-masing perlakuan menunjukkan pengaruh berbeda sangat nyata lebih tinggi $(\mathrm{P}<0.01)$ terhadap peningkatan jumlah total VFA dibandingkan dengan perlakuan lainnya.

Tingginya jumlah total VFA pada perlakuan A3Y1 (2000 ppm dan 10 hari) disebabkan karena kecernaan nutrient substrat juga lebih tinggi dibandingkan dengan perlakuan lainnya. Volatile Fatty Acid (VFA) yang terdapat di dalam rumen tidak hanya berasal dari hasil fermentasi karbohidrat, sebagian dapat berasal dari aktifitas mikroba rumen terhadap protein atau ikatan lain yang mengandung nitrogen (Anggorodi, 1979). Protein di dalam rumen dihidrolisis oleh enzim proteolitik yang dihasilkan oleh mikroba rumen menjadi peptida, peptida akan dihidrolisis menjadi asam-asam amino, kelebihan asam amino yang diperoleh dari hidrolisis protein akan dirubah menjadi asam $\alpha$-keto dan NH3. Asam $\alpha$-keto akan dirubah menjadi VFA (iso butirat, isovalerat dan 2 metil butirat) yang akan digunakan sebagai cadangan energi (Sutardi et al, 1983).

Rendahnya total VFA pada perlakuan A0 (0 ppm), A1 (1000 ppm), A2 (1500 ppm), Y2 (15 hari) dan Y3 (20 hari) disebabkan karena kecernaan nutrient substrat lebih rendah jika dibandingkan dengan perlakuan A3 (2000 ppm) dan Y1 (10 hari). Perbedaan jumlah VFA yang diperoleh sejalan dengan peningkatan kecernaan substrat. Total VFA yang diperoleh pada penelitian ini berkisar antara $97.53 \mathrm{mM}-121.25$ $\mathrm{mM}$, nilai ini sudah mencukupi kebutuhan mikroba rumen untuk berkembang dan tumbuh maksimal. Sutardi (1983) menyatakan bahwa kisaran total VFA yang dibutuhkan untuk pertumbuhan dan aktifitas mikroba secara maksimal adalah $80-160 \mathrm{mM}$ cairan rumen.

Peningkatan jumlah total VFA menunjukkan mudah atau tidaknya pakan didegradasi oleh mikroba rumen. Pada ruminansia VFA memiliki peranan ganda yaitu sebagai sumber energi dan sebagai sumber kerangka karbon bagi pembentukan protein mikroba (Sutardi, 1983). Produksi VFA yang tinggi merupakan kecukupan energi bagi ternak, VFA ini akan digunakan untuk pembentukan protein mikroba dengan adanya keseimbangan produksi NH3 dan VFA di dalam rumen akan meningkatkan sintesis protein mikroba yang dapat digunakan sebagai sumber protein berkualitas bagi induk semang (Sakinah, 2005).

Derajat Keasaman (pH).

Rataan perlakuan terhadap derjat keasaman $(\mathrm{pH})$ terhadap perlakuan dapat dilihat pada Tabel 3.

Tabel 3. Rataan $\mathrm{pH}$

\begin{tabular}{|c|c|c|c|c|c|}
\hline Waktu & & $\operatorname{Dosis}(\mathrm{A})$ & & & Rataan \\
\hline$(\mathbf{Y})$ & A0 & A1 & A2 & A3 & \\
\hline Y1 & 6.86 & 6.86 & 6.81 & 6.84 & 6.84 \\
\hline $\mathrm{Y} 2$ & 6.86 & 6.86 & 6.85 & 6.79 & 6.84 \\
\hline Y3 & 6.87 & 6.86 & 6.79 & 6.80 & 6.83 \\
\hline Rataan & 6.86 & 6.86 & 6.82 & 6.81 & 6.84 \\
\hline
\end{tabular}

Hasil sidik ragam menunjukkan bahwa pemberian perlakuan tidak berbeda nyata $(\mathrm{P}>0.05)$ terhadap $\mathrm{pH}$. Ini disebabkan karena adanya keseimbangan antara produksi VFA dan $\mathrm{NH} 3$. Nilai $\mathrm{pH}$ yang diperoleh berkisar antara $6.79-6.85$, nilai ini menunjukkan kondisi yang cukup menjamin untuk pertumbuhan mikroba rumen dengan optimal. Berarti fermentasi daun sawit dengan menggunakan kapang Phanerochaete chrysosporium mampu mempertahankan kadar $\mathrm{pH}$ cairan rumen. $\mathrm{pH}$ rumen yang ideal untuk perkembangbiakan mikroorganisme berkisar antara 6-7 (Church, 1988). Perbedaan $\mathrm{pH}$ yang tidak nyata antar perlakuan ini juga dipengaruhi oleh pemberian buffer Mc.Dougall (saliva buatan) yang berperan dalam mempertahankan $\mathrm{pH}$ rumen untuk tetap stabil (Church, 1988). 


\section{KESIMPULAN}

Fermentasi daun sawit dengan menggunakan kapang Phanerochaete chrysosporium pada dosis mineral Ca 2000 ppm dengan lama fermentasi 10 menghasilkan total VFA $121.25 \mathrm{mM}$ yang lebih banyak dibandingkan dengan perlakuan lainnya serta jumlah NH3 yang dihasilkan $14.80 \mathrm{mg} / 100 \mathrm{ml}$ cairan rumen sedangkan $\mathrm{pH}$ berkisar 6.79 6.86. $\mathrm{pH}$ yang dihasilkan masih dalam kondisi dimana mikroba rumen dapat tumbuh dengan optimal, sehingga hasil fermentasi ini dapat digunakan sebagai bahan penyusun ransum ternak.

\section{DAFTAR PUSTAKA}

Anggorodi, R. 1979. Ilmu Makanan Ternak Umum. PT. Gramedia. Jakarta.

Alimon, A.R. and M. Hair-Bejo. 1996. Feeding system based on oil palm by-product in Malaysia. Proc. of the First International Symposium on the Integration of Livestock to Oil Palm Production. Kuala Lumpur, Malaysia 25 - 27 May 1995.

Church, D.C. 1988. The Ruminant Animal Digestive Physiology and Nutrition. Prentice Hall, Englewood Cliff, New York.

Leisola, M. S., S. Garcia. 1989. The Mechanisme of Lignin Degradation. Finnish Sugar Co. Ltd. Research Centre. Kantvik. Finland. Wulandari, S., R. Hidayat., Suryadi dan T. Toharmat. 2003. Pengaruh prehidrolisis enzimatis dari Phanerochaete crysosporium dan pemberian in nokulan Lactobacillus plantarium terhadap nilai nutrisi silase rumput gajah. J. Indon. Trop. Anim. Agric. Special Edition (Oktober) 2003.

Nelson. 2011. Degradasi bahan kering dan produksi asam lemak terbang in vitro pada kulit buah kakao fermentasi. Jurnal Ilmiah Ilmu-Ilmu Peternakan. Vol.XIV.No1.

Nelson dan Suparjo. 2011. Penentuan lama fermnetasi kulit buah kakao dengan Phanerochaete chrysosporium evaluasi kualitas nutrisi secara kimiawi. Agrinak.Vol.01(1):1-10. ISSN: 20888643.

Sakinah, D. 2005. Kajian suplementasi probiotik bermineral terhadap produksi VFA, NH3 dan kecernaan zat makanan pada domba. Skripsi Fakultas Peternakan IPB. Bogor.
Sayuti, N. 1989. Ruminologi. Diktat Fakultas Peternakan Universitas Andalas, Padang.

Sirait, J., N.D. Purwantari dan K. Simanihuruk. 2005. Produksi dan serapan nitrogen rumput pada naungan dan pemupukan yang berbeda. Dalam Simanihuruk, K., J. Sianipar., L.P. Batubara., A. Tarigan., R. Hutasoit., M. Hutauruk., Supriyatna., M. Situmorang dan Trayono. 2007. Pemanfaatan pelepah kelapa sawit sebagai pakan basal kambing kacang fase pertumbuhan. Seminar Nasional Teknologi Peternakan dan Veteriner. Loka Penelitian Kambing Potong. Sungei Putih.

Steel, R. G. D and J. H. Torrie. 1991. Prinsip dan Prosedur Statistika. Suatu Pendekatan Biometrik. Terjemahan. Edisi Kelima. PT. Gramedia Pustaka Utama, Jakarta.

Sutardi, T. 1980. Landasan Ilmu Nutrisi. Jilid I. Departemen Ilmu Makanan Ternak. Fakultas Pertanian, IPB. Bogor.

Sutardi,T. 1981. Pemanfaatan limbah perkebunan sebagai pakan ternak ruminansia. Makalah Seminar Fakultas Peternakan. Institut Pertanian Bogor. Bogor.

Sutardi, T., N. A. Sigit dan T. Toharmat. 1983. Standarisasi mutu protein bahan makanan ruminansia berdasarkan parameter metabolismenya oleh mikroba rumen. Laporan Penelitian Direktorat Pembinaan dan Pengabdian pada Masyarakat. Direktorat Jenderal Pendidikan Tinggi Departemen Pendidikan dan Kebudayaan.

Rahayu, S. 2014. Biodelignifikasi Daun Sawit dengan Menggunakan Kapang Phanerochaete chrysosporium yang disuplementasi dengan Mineral $\mathrm{Ca}$ dan Evaluasi Kecernaan Secara In vitro. Thesis. Program Pascasarjana Ilmu Peternakan. Universitas Andalas.Padang 